\title{
Bearing capacity characteristic of subgrade layer quicklime treated laterite soil
}

\author{
Zubair Saing ${ }^{1,{ }^{*}, \text { Lawalenna Samang }^{1}, \text { Tri Harianto }^{1} \text {, and Johannes Palanduk }}{ }^{1}$ \\ ${ }^{1}$ Hasanuddin University, Department of Civil Engineering, Gowa, Indonesia
}

\begin{abstract}
This study aimed to analyze bearing capacity characteristics of laterite soil with quicklime stabilization as road subgrade layer. The laterite soil obtained from three different locations with three different ferrous $(\mathrm{FeO})$ content. Soil samples were conduct by mixing laterite soil with $3 \%$, $5 \%, 7 \%$, and $10 \%$ lime content on Proctor initial condition, then cured for 3,14 , and 28 days before tested for soil bearing capacity using CBR laboratory test. Result showed that the lime treated laterite soil increases the bearing capacity for all types of laterite soil significantly in line with incrasing of lime content on 28 days curing time $(11,67 \%$ to $51,67 \%, 14 \%$ to $53,33 \%$, and $14,17 \%$ to $71,67 \%$, respectively for LH1, LH2 and LH3). The increasing of soil bearing capacity due to pozzolanic strength gain. Based on these results, the laterite soil has potentially to be used as road subgrade layer.

Keywords: Road foundation, laterite soil, quicklime stabilization, soil performance
\end{abstract}

\section{Introduction}

Indonesia's current development has generated efforts to manage economic resources in the community. Local natural resources are very potential to require innovation for its utilization. This is mainly due to the high competition and cost to obtain these materials. In addition, various studies are underway to find a better way to achieve this goal, a way that will cost less and be more economical when compared to using materials that naturally meet the requirements standards. In line with this, the material required for infrastructure development intended to increase, especially for construction and road foundation material. Certain areas have limited resources to qualified material, especially material (grade) A and B. One such area is particularly the Sorowako in South Sulawesi, which has been buying material from other areas to be used as road foundation material. On the other hand, the local content materials has potential to be developed as a replacement material for road subgrade layer, one of them is laterite soil.

Laterite soil containing the clay minerals are relatively high mainly illite and montmorillonite, so greater damage potentially if carried out construction work on the soil like this [1]. Clay minerals and metals are high, it can be used for various needs of both the construction, industry, and others. Laterite soil is soil groups result from highly weathering

* Corresponding author: zubairsaing.ummu@gmail.com 
zone, formed from the concentration of hydrated iron oxide and aluminum, soil characteristics of this type have a hard, impenetrable, and very difficult to change if the conditions dry [2]. Laterite have a wide variety of red, brown to yellow, fine grain sized residual soil with a granular texture have a mild form nodular and well cemented. The correct use of the term laterite is a compact rock formations vesicular iron (a massive vesicular or concretionary ironstone formation). Laterite based on hardening as "freeic" for hard soil cemented iron rich, "alcrete" or bauxite for hard soil cemented aluminum rich, "calcrete" for hard soil calcium carbonate rich, and "silcrete" for soil in silica rich. Other definitions are based on the ratio of silica ( $\mathrm{SiO} 2)$ to oxide $(\mathrm{Fe} 2 \mathrm{O} 3+\mathrm{Al} 2 \mathrm{O} 3)$, for laterit such comparisons between 1.33 and 2.0, while above 2.0 is not laterit.

Research on lateritic soil has been widely applied, especially in countries that there are many types of soil such as in Asia and Africa. The higher of clay minerals content in laterite soil causing the strength decreases [3]. Laterite soil stabilization with lime will increase the strength becomes 2-3 times [2]. Addition of a little lime and cement highly efficient, improve laterite soil by adding $3 \%$ only $2 \%$ of cement and lime [1]. Laterite soil stabilization using polymer solution (GKS) has increasing of soil strength with increasing curing time after 7 days [4]. Laterite soil stabilization using ash cane fiber is very effective in stabilizing and strengthening the geotechnical properties of soil [2]. Laterite soil stabilized with ash cane and cement is very effective as a stabilizing agent in the content of $6 \%$ and $5 \%$ of the cement to reinforce the geotechnical properties of soil, and can be used for construction road as a subbase [5]. Stabilization using corn cob ash (CCA) has caused the maximum dry density decreases in ash content of $1.5 \% \mathrm{CCA}$, optimum water content increased in the binder content of 0 to $7.5 \%$. CBR value increased at the CCA content of $1.5 \%$, and then decreased with the addition of CCA. Unconfined compression strength also increased on 1.5\% CCA content, and decreased with the addition of CCA [6]. Laterite soil stabilization using sodium silicate liquid indicate that the addition of sodium silicate over $9 \%$ decrease the compressive strength of the soil [7]. Laterite soil characteristics as a coating material that is fed gasoline, hydraulic conductivity increases in line with the increase in hydraulic gradient [8]. Lateritic soil with high liquid-limits is commonly used for roadbed construction. However, lateritic soil has properties that are sensitive to moisture, and therefore a common method of treating the soil is by adding lime. However, it is difficult to mix lime with lateritic soil homogeneously in the field as lateritic soil is prone to agglomeration. Lime $(\mathrm{Ca}(\mathrm{OH}) 2)$ is added to one of the groups of soil samples and the other group is left untreated. The maximum CBR value is not consistent with maximum dry density. Moreover, the CBR values of soil has been treated with lime are higher than the untreated soil for an agglomerate size that ranges from $0.5 \mathrm{~mm}$ to $2 \mathrm{~cm}$. Beyond this range, the addition of lime does not improve the lateritic soil. Compaction status and water intrusion are two important influential factors on CBR values [9]. The potentially of laterite soil with lime and cement stabilization as a road foundation [10-15].

The growing research on the utilization of laterite soil, indicating that the soil is very potential to be used in various constructions. However, still not much research on laterite soil with higher iron metal content (ferro laterite soil). This study was conducted to analyze the bearing capacity characteristics of laterite soil with quicklime stabilization as road subgrade layer.

\subsection{Material and method}

The material used in this research is laterite soil with higher ferrous content from Sorowako East Luwu Regency South Sulawesi on coordinate S $2^{\circ} 56{ }^{\prime} 21,16^{\prime \prime}$ and E 121 $366^{\prime} 26,54^{\prime \prime}$ as shown in Figure 1. Tests of physical and mechanical properties of the soil were conducted in laboratory according to American Standard for Testing and Materials (ASTM), as shown 
in Table 1. Soil stabilization using quicklime with $\mathrm{CaO}=97,8 \%$ and silica oxide $\left(\mathrm{SiO}_{2}\right)=$ $2,2 \%$. The addition of lime with compositions of 3,5,7, and $10 \%$ at maximum dry density from Proctor standard test. Sample was cured for 3, 14, and 28 days before CBR laboratory testing, with the total number of samples tested was 108. Microstructural testing were conducted to knows the micro condition of treated and untreated soil. This test using X-ray diffraction (XRD) for minerals content and Scanning Electron Microscope (SEM) for photomicrograph. While chemical content using Energy Dispersive Spectorscopy (EDS) test.

Table 1. The standard test used

\begin{tabular}{|l|l|}
\hline Type of Testing & \multicolumn{1}{|c|}{$\begin{array}{c}\text { ASTM Standard } \\
\text { Number }\end{array}$} \\
\hline Grain Size Analisys & C-136-06 \\
\hline Liquid Limit (LL) & D-423-66 \\
\hline Plastic Limit (PL) & D-424-74 \\
\hline Plasticity Index (IP) & D-4318-10 \\
\hline Spesific Gravity (Gs) & D-162 \\
\hline Water Content (Wc) & D-2216-98 \\
\hline Uniconfined Compression Test (qu) & D-633-1994 \\
\hline Compaction Test & D-698 \\
\hline CBR Laboratory Test & D-1833 \\
\hline
\end{tabular}

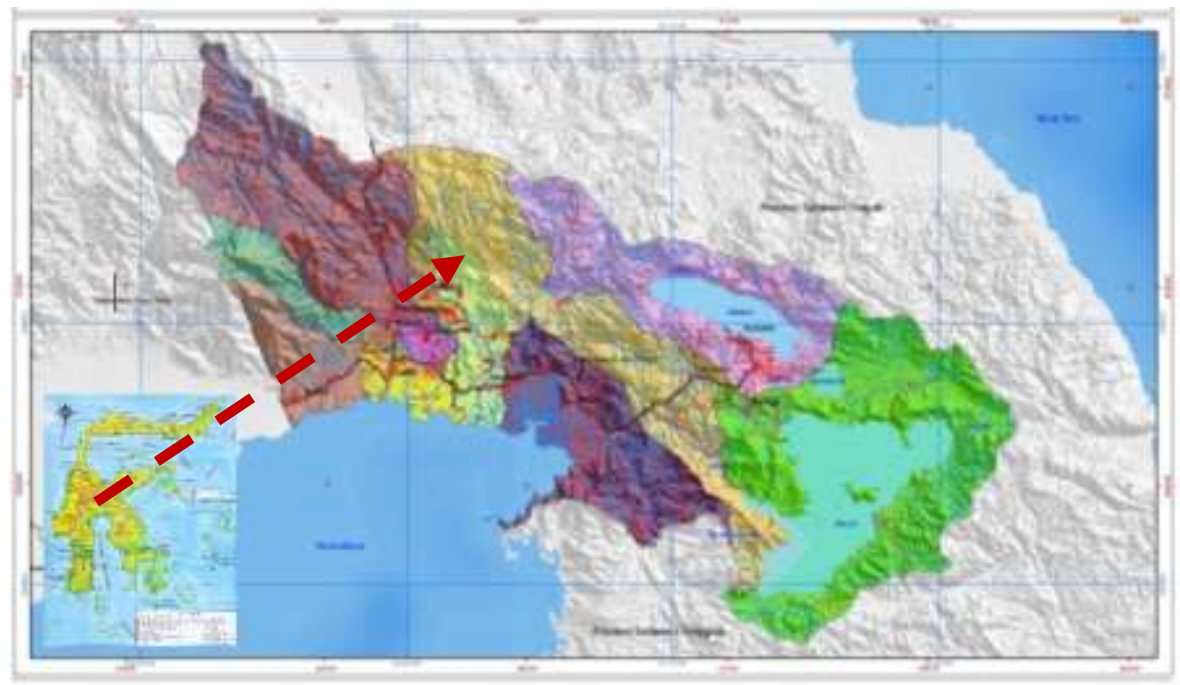

Figure 1. Sampling location of laterite soil

\section{Discussion}

Testing of the soil basic properties including; specific gravity, soil moisture content, soil density, Atterberg limits, and soil grain size analysis. Tests carried out on the laterite soil for three types with three different locations using ASTM standard test such as Table 1. Results of laboratory tests for physical and mechanical properties as well as chemical and mineral properties as shown in Table 2, 3, and 4. 
Table 2. Physical properties of laterite soil

\begin{tabular}{|c|c|c|c|c|c|}
\hline No & Soil Characteristics & Unit & LH1 & LH2 & LH3 \\
\hline 1 & Specific gravity (Gs) & - & 2,73 & 2,62 & 2,66 \\
\hline 2 & Water content (w) & $\%$ & 20,26 & 22,25 & 18,86 \\
\hline \multirow[t]{4}{*}{3} & Sieve analysis & & & & \\
\hline & a. gravel & $\%$ & - & - & - \\
\hline & b. sand & $\%$ & 7,69 & 5,11 & 8,25 \\
\hline & c. Silt/clay & $\%$ & 92,31 & 94,89 & 91,75 \\
\hline \multirow[t]{4}{*}{4} & Consitency limits & & & & \\
\hline & a. Liquid limt (LL) & $\%$ & 65,98 & 68,73 & 67,77 \\
\hline & b. Plastic limit (PL) & $\%$ & 35,92 & 37,96 & 36,86 \\
\hline & c. Plasticity Index (PI) & $\%$ & 30,06 & 30,77 & 30,91 \\
\hline \multirow[t]{3}{*}{5} & Standard Proctor test & & & & \\
\hline & a. Maximum dry density ( $\square_{\text {d maks }}$ ) & $\mathrm{kN} / \mathrm{m}^{3}$ & 16,91 & 16,92 & 16,89 \\
\hline & b. Optimum water content ( $\left.\mathrm{w}_{\mathrm{opt}}\right)$ & $\%$ & 17,23 & 16,72 & 16,53 \\
\hline 6 & Unconfined compression strength $\left(\mathrm{q}_{\mathrm{u}}\right)$ & $\mathrm{kN} / \mathrm{m}^{2}$ & 71,44 & 128,88 & 75,61 \\
\hline \multirow[t]{2}{*}{7} & $\begin{array}{l}\text { California Bearing Ratio (CBR) } \\
\text { a. CBR unsoaked }\end{array}$ & $\%$ & 11,77 & 22,99 & 22,80 \\
\hline & b. CBR soaked & $\%$ & 7,67 & 10,33 & 8,50 \\
\hline \multirow[t]{3}{*}{8} & Direct shear test & & & & \\
\hline & a. Cohesion (C) & $\mathrm{kN} / \mathrm{m}^{2}$ & 15,2 & 16,3 & 14,7 \\
\hline & b. Internal friction angle ( $\square$ ) & $\left({ }^{\circ}\right)$ & 18 & 20 & 19 \\
\hline
\end{tabular}

Table 3. Chemical properties of laterite soil obtained from EDS test

\begin{tabular}{|l|c|c|c|}
\hline \multirow{2}{*}{$\begin{array}{c}\text { Element } \\
(\%)\end{array}$} & \multicolumn{3}{|c|}{ Laterite Soil } \\
\cline { 2 - 4 } & $\mathbf{L H 1}$ & $\mathbf{L H 2}$ & $\mathbf{L H 3}$ \\
\hline $\mathrm{MgO}$ & 2,33 & 0,83 & 1,28 \\
\hline $\mathrm{Al}_{2} \mathrm{O}_{3}$ & 4,41 & 5,73 & 8,45 \\
\hline $\mathrm{SiO}_{2}$ & 12,58 & 2,28 & 3,71 \\
\hline $\mathrm{K}_{2} \mathrm{O}$ & 0,1 & & \\
\hline $\mathrm{TiO}_{2}$ & 0,08 & & \\
\hline $\mathrm{FeO}$ & 80,5 & 86,55 & 84,88 \\
\hline $\mathrm{SO}_{3}$ & & 1,05 & \\
\hline $\mathrm{CaO}$ & & 0,25 & \\
\hline $\mathrm{MnO}$ & & 0,24 & \\
\hline $\mathrm{NiO}$ & & 2,78 & 1,38 \\
\hline
\end{tabular}

Table 4. Mineral content of laterite soil obtaned from XRD test

\begin{tabular}{|l|c|c|c|}
\hline \multirow{2}{*}{\multicolumn{1}{|c|}{ Mineral Content (\%) }} & \multicolumn{3}{c|}{ Laterite Soil } \\
\cline { 2 - 4 } & LH1 & LH2 & LH3 \\
\hline Hematite HP, iron(III) oxide & 13 & 7 & 1 \\
\hline Kaolinite & 20 & 8 & 67 \\
\hline Illite-montmorillonite (NR) & 60 & 80 & 18 \\
\hline rutile HP & 1 & 2 & 11 \\
\hline Magnesium Silicate & 6 & 3 & 3 \\
\hline
\end{tabular}


Based on the results of Tables 2, it is known that laterite soil grains are dominated by silt/clay material of $91,75-94.89 \%$, with plasticity index of $30,66 \%-30,91 \%$. These results indicate that laterite soils are included in clay classification with high plasticity (A-7-6 according to AASTHO and CH according to USCS). While based on chemical composition on Table 3, showed that laterite soil was dominated by iron oxide content of $80,50 \%$ $86.55 \%$, and based on showed on Table 4, laterite soils are dominated by illitemontmorillonite minerals of $18 \%-80 \%$.

Subsequently, bearing capacity of lime treated laterite soil obtained from laboratory CBR test. The change of CBR value lime treated laterite soil of 3, 5, 7, and 10\% with curing time of 3, 14, and 28 days as shown in Figure 2.
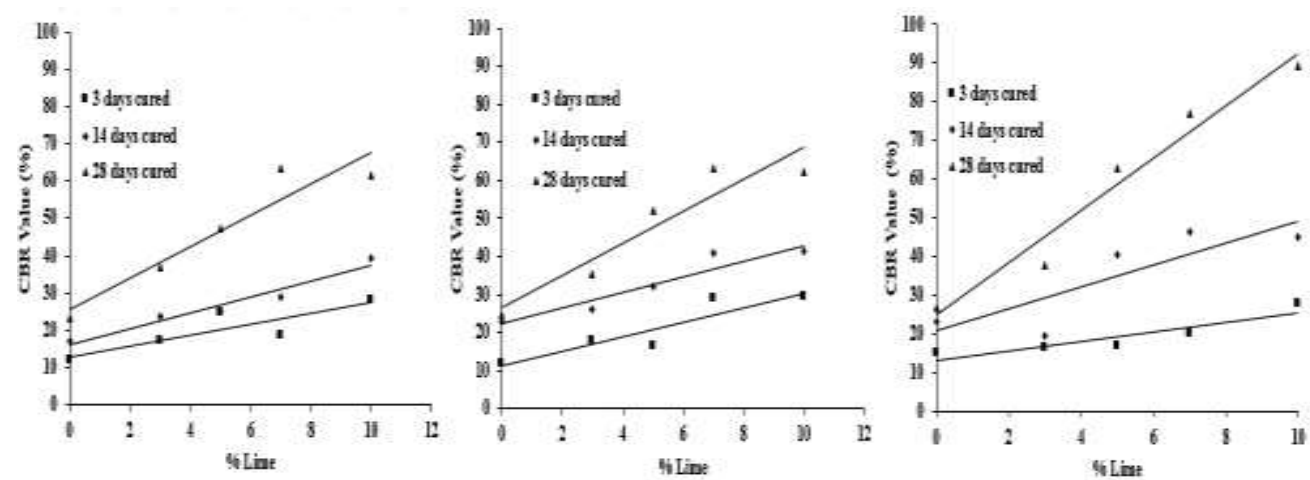

Figure 2. Correlation of CBR value with lime addition and curing time of laterite soil

Based on Figure 2, it can be seen the change of CBR value of laterite soil with addition lime content and curing time. Increasing of lime content and curing time caused the increasing of soil CBR value. Pozzolanic strength gain due to pozzolanic reaction in soil cause the increasing of soil strength and soil bearing capacity. Increased of CBR value lime treated laterite soil are $11.67 \%$ to $51.67 \%$ for $\mathrm{LH} 1,14 \%$ to $53.33 \%$ for $\mathrm{LH} 2$, and $14.17 \%$ to $71.67 \%$ for LH3. The increase in strength and bearing capacity of soil occurs due to the addition of lime to the soil undergoing three processes, namely the hydration of lime hydration, cation exchange reactions, and the reaction of pozzolanic carbonation [16] The process of lime hydration is a chemical reaction between lime with water in which calcium hydroxide or lime hydration $\left(\mathrm{Ca}(\mathrm{OH})_{2}\right)$ is formed. These reactions include the exchange of calcium ions $\left(\mathrm{Ca}^{2+}\right)$, adsorption of $\mathrm{Ca}(\mathrm{OH})_{2}$ by particles and cementation on inter-particle contact calcium silicate. The cation exchange reaction includes the substitution of $\mathrm{Na}^{+}$and $\mathrm{H}^{+}$ions in the soil with $\mathrm{Ca}^{2+}$ ions from lime. The clay particles continuously absorb $\mathrm{Ca}(\mathrm{OH})_{2}$ until saturated. This exchange reduces plasticity, improves performance, and soil strength. This reaction occurs immediately when mixing the stabilization material into the soil. Pozzolanic reactions and carbonization include the reaction between clay particles with $\mathrm{Ca}(\mathrm{OH})_{2}$ produced by lime. This contributes to the long-term strength of pozzolanic materials. The strength of the degraded soil increases with the timing of this reaction. Calcium hydroxide in the soil-water reaction with silicate and aluminate in the soil form a sterilized material or a binder comprising calcium silicate hydrate (CSH). In line with the occurrence of a pozzolanic reaction, the $\mathrm{CASH}$ is slowly transformed into a crystalline phase in the form of calcium silicate hydrate $(\mathrm{CSH})$ and calcium aluminum hydrate $(\mathrm{CAH})$ which suffers from hardening over time to form a permanent mixture that binds soil particles. This condition causes an increase in soil strength and soil bearing capacity. This condition also seen from the results of microstructural (SEM Photomicrograph) tests as in Figure 3. 

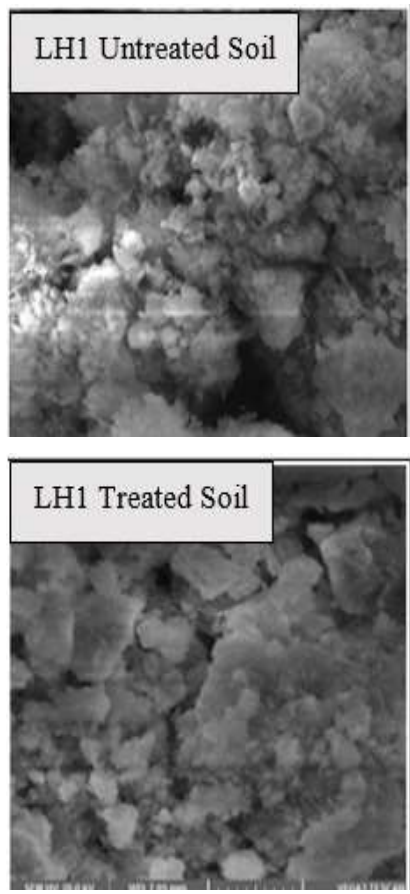
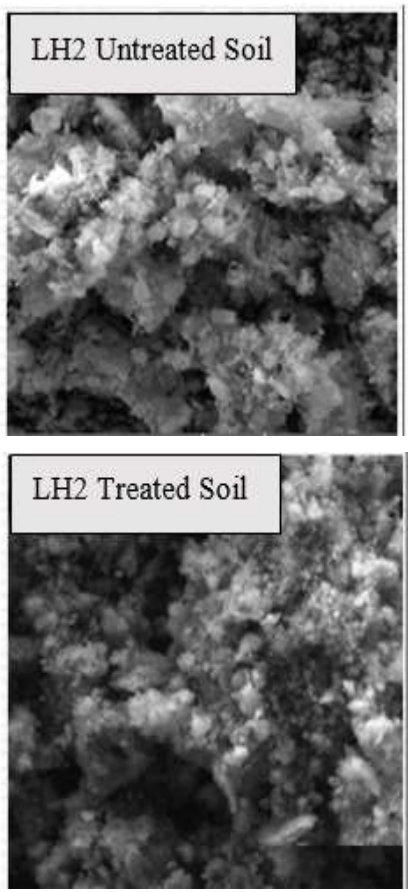
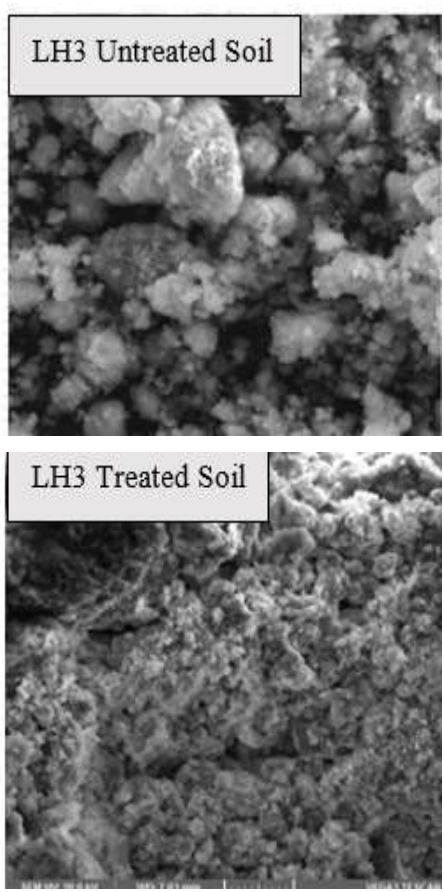

Figure 3. SEM Photomicrograph of laterite soil

Based on Figure 3, it can be seen that untreated laterite soil has large micropore structure, after treated the flocculation and agglomeration structures form calcium silicate hydrate $(\mathrm{CSH})$ ions that cover the pores, resulting in smaller pores and soil fabric become more solid [7].

\section{Conclusions}

In this paper, three different ferro laterite soils treated with lime for road subgrade layer was studied. The main aim was to analyze the bearing capacity characteristics of laterite soil with quicklime stabilization as road subgrade layer. Based on physical properties, the laterite soil was A-7-6 for AASHTO soil classification system and $\mathrm{CH}$ for USCS soil classification system. An increasing percentage of the lime addition $(\mathrm{CaO})$ and increased curing time lead to increased soil bearing capacity, on $10 \%$ lime mixture and 28 days curing time increase three time than untreated soil. Based on these results, the treated laterite soil has potentially to be used as road subgrade layer, but it should be tested in detail of physical model before field implementation.

\section{References}

1. F.H.M. Portelinha, D.C. Lima, M.P.F. Fontes, C.A.B. Carvalho, Modification of a Lateritic Soil with Lime and Cement: An Economical Alternative for Flexible Pavement Layers, Soils and Rocks, São Paulo, 35(1): 51-63, January-April, 2012, pp 51-63. (2012)

2. Amu, O.O., Ogunniyi, S.A. and Oladeji, O.O., Geotechnical properties of lateritic soil stabilized with sugarcane straw Ash, American Journal of Scientific and Industrial Research, Science Huß, 2(2) pp. 323-331 (2011) 
3. Sree Danya, Ajitha, A.R, Evangeline, Y. Sheela., The Suitability and Lime Stabilization Requirement of Some Lateritic Soil Samples as Pavemen, Int. J. Pure Appl. Sci. Technol., 2(1), pp. 29-46. (2010)

4. Aminaton Marto, Nima Lativi, Houman Souhaei, Stabilization of Laterite Soil using GKS Soil Stabilizer, EJGE Journal, Vol 18, Bund. C, pp 521-532 (2013)

5. Kiran, S.P., A.N Ramakrishna, Shrinivas. H.R, Stabilization of Lateritic Soil by using Sugarcane Straw Ash and Cement, Journal of Civil Engineering Technology and Research, 2 (1) pp.615-620. (2014)

6. Yinusa A. Jimoh, O. Ahmed Apampa, An Evaluation of the Influence of Corn Cob Ash on the Strength Parameters of Lateritic Soils, Civil and Environmental Research, 6 (5) No.5. (2014)

7. Nima Latifi, Amin Eisazadeh, Aminaton Marto, Strength behavior and microstructural characteristics of tropical laterite soil treated with sodium silicate-based liquid stabilizer, Environ Earth Sci 72:91-98 DOI 10.1007/s12665-013-2939-1, SpringerVerlag Berlin Heidelberg. (2014)

8. Wisley Moreira Farias, Geraldo Resende Boaventura, Éder de Souza Martins, Fabrício Bueno da Fonseca Cardoso, José Camapum de Carvalho and Edi Mendes Guimarães., Chemical and Hydraulic Behavior of a Tropical Soil Compacted Submitted to the Flow of Gasoline Hydrocarbons, Environmental Risk Assessment of Soil Contamination, Intech, pp 638-655. (2014)

9. Yunzhi Tan, Mozhen Hu, Dianqing Li, Effects of agglomerate size on California bearing ratio of lime treated lateritic soils, International Journal of Sustainable Built Environment, 5, pp. 168-175, Elsevier B.V. All rights reserved. (2016)

10. Saing, Z., Samang, L., Haryanto, T. and Patanduk, J., "Microstructural and Mechanical Characteristic of Potential Ferro Laterite Soil as Subbase Material", International Journal of Innovative Research in Advance Engineering, 3 (2), pp 42-48. (2014)

11. Saing, Z., Samang, L., Harianto, T. and Patanduk, J., "Quick Lime Stabilization of Ferro Laterite Soil to Subgrade Material Implementation", International Journal of Science and Research, 5 (11), pp 582-586. (2016)

12. Zubair Saing, Lawalenna Samang, Tri Harianto and Johannes Patanduk, "Mechanical Characteristic of Ferro Laterite Soil with Cement Stabilizationas a Subgrade Material", International Journal of Civil Engineering and Technology, 8(3), pp. 609-616. (2017)

13. Zubair Saing, Vertical Deformation of Lime Treated Base (LTB) Model of Laterite Soil using Numerical Analysis. International Journal of Civil Engineering and Technology, 8(5), pp. 758-764. (2017)

14. Zubair Saing, Vertical Deformation of Lime Treated Base (LTB) Model of Laterite Soil using Numerical Analysis. International Journal of Civil Engineering and Technology, 8(5), pp. 758-764. (2017)

15. Saing Z, Samang L, Harianto T, Patanduk J, "Study on Characteristic of Laterite Soil with Lime Stabilization as a Road Foundation, International Journal of Applied Engineering Research, 12(14), pp. 4687-4693. (2017)

16. Jaritngam S, O. Somchainuek, and P. Taneerananon, "Feasibility of Laterite-Cement Mixture as Pavement Base Course Aggregat", International Journal of Science and Technology Transaction of Civil Engineering Vol. 38. No. C1+, pp. 275-284. (2014)

17. Olugbenga O Amu, Oluwole F.B., dan Iyiola A.K., The Suitability and Lime Stabilization Requirement of Some Lateritic Soil Samples as Pavemen, Int. J. Pure Appl. Sci. Technol., 2(1), pp. 29-46. (2011) 